\title{
Kłopoty z Deotymą
}

\author{
Agnieszka BĄBel \\ (Instytut Badań Literackich PAN)
}

\section{i. Kim jest Deotyma?}

Jadwiga Łuszczewska, w słownikach biograficznych, wspomnieniach i encyklopediach znacznie lepiej znana pod swym najpopularniejszym artystycznym pseudonimem Deotymy ${ }^{\mathrm{I}}$, jest dla polskiej literatury postacią kłopotliwą. Jako improwizatorka, poetka i pisarka bywała niesłychanie popularna i niemal zupełnie zapomniana, adorowana do granic bałwochwalstwa i wykpiwana w wyjątkowo brutalny sposób. Nie ma zgody co do oceny jej dorobku artystycznego, którego wartościowanie bardzo się zmieniało, można spotkać się też z diametralnie różnymi ocenami jej wyborów życiowych i charakteru. W osobliwy sposób już za życia niejako przestała być realną kobietą, stając się symbolem pewnego zjawiska kulturowego, charakterystycznego dla swojej epoki: salonu literackiego i sztuki improwizacji - zachowując odpowiednie proporcje, można by nieco prowokacyjnie powiedzieć, że Deotyma na swój sposób jest miniaturową królową Wiktorią dziewiętnastowiecznego warszawskiego salonu. Polska „królowa ideału” posiadała oczywiście w świecie „dobrego tonu" wpływy mocno ograniczone i władzę nieporównanie bardziej iluzoryczną niż jej koronowany brytyjski odpowiednik, jednak w przypadku obu tych postaci można zaobserwować analogiczne zjawisko: stają się one mianowicie projekcjami wyobrażeń swoich admiratorów i krytyków, a ich istota zmienia się w zależności od kontekstu, w którym są osadzone ${ }^{2}$. Wiktoria była wszak „matką narodu”,

1 Jadwiga Łuszczewska improwizowała jako Deotyma (Deotima, Diotima), natomiast teksty podpisywała również pseudonimami i kryptonimami: Bog...na, Bogobojna, Ja. Ł, Jad. Ł, Niwadija (A. Biernacki, hasło: Euszczerwska Jadwiga, w: Polski stownik biograficzny, t. XVIII, Wrocław-Warszawa-Kraków-Gdańsk 1973, s. 581). We wszystkich cytatach zachowano pisownię i wyróżnienia oryginału.

2 Dorota Babilas tak pisze o wyobrażeniu monarchini w kulturze: „W epoce postmodernizmu królowa Wiktoria, można rzec, uległa sklonowaniu, rozpadła się na konkurujące ze sobą obrazy, stając się tym sposobem wyrazicielką nie tyle własnej biografii, co specyficznej epoki historycznej nazwanej jej imieniem. Niezależnie od tego, czy Wiktoria osobiście mogłaby być zaklasyfikowana jako 
uosobieniem wartości rodzinnych, domową despotką, bolejącą wdową, symbolem trwałości Imperium i pruderyjnej, pełnej hipokryzji moralności, zależnie od tego, kto tworzył jej obraz. Sięgając do wspomnień z epoki, wypowiedzi krytycznych i opracowań naukowych, możemy dostrzec równie wieloznaczny, kontrastowy, pełen nieprawdopodobnych sprzeczności portret Deotymy: wzniosła i śmieszna, natchniona wieszczka, geniusz poezji i pretensjonalna grafomanka; uosobienie pokory i istota za wszelką cenę łaknąca „kadzidła pochlebstw”; ciężko pracujący rzemieślnik słowa i nieznosząca żadnych sprzeciwów „poetessa”, gotowa posunąć się do mistyfikacji dla podtrzymania kultu własnej osoby; bezgranicznie oddana córka i rozgoryczona ofiara ambicji własnej matki; wierna przyjaciółka i kobieta o zimnym sercu, organicznie niezdolna do miłości; żarliwa patriotka i wyrachowana oportunistka, wisząca u carskiej klamki; wyznawczyni płytkiego konwenansu i buntowniczka... Kim była Deotyma?

W tym tekście nie mam ambicji udzielenia ostatecznej odpowiedzi na to pytanie - chciałabym natomiast przez ukazanie kilku wybranych, sprzecznych ocen i wypowiedzi utrzymanych niekiedy w zdumiewająco agresywnym tonie zastanowić się, co w Jadwidze Łuszczewskiej, jej twórczości, a także charakterze i sytuacji życiowej mogło być tak prowokującego i irytującego dla jej krytyków, współczesnych i potomnych? Dlaczego, uosabiając pewne zjawisko kulturowe charakterystyczne dla swoich czasów, zarazem zdawała się do tych czasów nie pasować? W tym celu jako punkt odniesienia posłużą (nieczęste, lecz tym cenniejsze) wypowiedzi badaczy pisane sine ira et studio ${ }^{3}$, a także głos samej Deotymy, przede wszystkim w postaci jej wspomnień, napisanych w I897 roku i udostępnionych w postaci odpisów wąskiemu gronu czytelników, wydanych zaś drukiem dopiero dwa lata po jej śmierci, w I9ıo

«Wiktorianka», w swoim kulturowym wizerunku jest uosobieniem wiktorianizmu, ze wszystkimi jego dychotomiami i problemami, jakie stwarza kolejnym pokoleniom interpretatorów wywodzących się tak z prawej, jak i z lewej strony sceny politycznej. Jedną z najistotniejszych cech postrzegania królowej Wiktorii w kulturze jest jej «liminalność», czyli stan niedookreślenia, zawieszenia między dwoma jasno zdefiniowanymi grupami czy pojęciami. Jako suwerenna monarchini w dobie demokracji parlamentarnej, jako znak ideologii kolonializmu służący zniewoleniu podporządkowanych ludów, jako kobieta na tronie w czasach odmawiających kobietom politycznych praw - Wiktoria podważa obowiązujące reguły świata, który ma uosabiać” (D. Babilas, Wiktoria znaczy zwycięstwo. Kulturowe oblicza brytyjskiej królowej, Warszawa 2012, s. 11).

3 Zob. uwagi Henryka Markiewicza o powieściach Deotymy (zwłaszcza Panience z okienka) oraz o poemacie Sobieski pod Wiedniem, podkreślające „łagodną ironię” i „powściągliwy humor” autorki (idem, Pozytywizm, Warszawa 1999, s. 215, 308), bardzo cenne informacje w przypisach do: (Deotyma (Jadwiga Łuszczewska), Pamiętnik 1834-1897, wstępem i przypisami opatrzył J.W. Gomulicki, Warszawa 1968 - cytaty z Pamiętnika wraz z przypisami oznaczano dalej symbolem „P” z podaniem numeru strony), a zwłaszcza dotyczące wczesnego okresu twórczości Łuszczewskiej niedawne artykuły Izabeli Woszczak: Sekrety i porywy póznej twórczości, czyli o przyjaźni, wzajemnej fascynacji i rozczarowaniach taczacych Franciszka Wężyka, Kajetana Kożmiana i Antoniego Edwarda Odyńca z Deotyma, „Prace Polonistyczne”, seria 67, 2012 oraz Deotyma (Jadwiga Euszczewska) w witrynie artystycznej erwaluacji pierwszego okresu twórczości (1851-1863): prasa, wspomnienia, korespondencja, „Prace Polonistyczne”, seria 69, 2014. 
roku ${ }^{4}$ (oczywiście, głos ten nie będzie traktowany jako obiektywna prawda, lecz jako utrwalona wizja własnej osoby, konfrontowana z cudzymi opiniami). Niezmiernie istotny stanie się tu również wspomniany już kontekst - w przypadku Deotymy bowiem osobiste upodobania, powiązania towarzyskie i uwarunkowania biograficzne krytyków czy autorów wspomnień okazują się wywierać niezwykle wyraźny wpływ na ich oceny. Dopiero wiedząc, kto patrzy, możemy oszacować, co w istocie widzi.

\section{KRYTYKA - OBIEKTYWIZM CZY ZAANGAŻOWANIE?}

Znakomitym przykładem wypowiedzi krytycznej, której wymowa ulega pewnemu zniuansowaniu, jeśli opatrzyć ją informacjami dotyczącymi autora, jest podzielony na 4 części obszerny artykuł Życie fikcyjne i obrzędowe. (Przyczynek do studium nad Deotyma i kierunkiem naszej literatury), wydrukowany w „Przeglądzie Tygodniowym” w numerach I6-I9 w I883 roku. W życiu urodzonej w I834 roku Łuszczewskiej to okres, w którym, jak sama oceniała, zbliżyła się już nieco do dojrzałości twórczej, porzucając improwizacje i drobne wiersze, zajmując się natomiast powieściopisarstwem i przygotowując do pisania dzieł poetyckich o tematyce historycznej. Ukazały się drukiem trzy jej powieści: Na rozdrożu (1877), Krzyż nad otchtaniq (I878) i Zwierciadlana zagadka (I879). Nie bez przyczyny w pamiętniku okres ten opisywała w rozdziale $O$ wtasnych skrzydtach - dramatycznej zmianie uległa też jej sytuacja osobista, bowiem pochowała już wtedy oboje rodziców (ojca w 1867, matkę w I869 roku). Własny salon poetki otworzył podwoje po odbyciu przez nią okresu żałoby, w I87I roku, na regularnych czwartkowych spotkaniach o dość teatralnym charakterze gromadząc niekiedy grono „wybrańców”, dochodzące do stu osób5

4 Deotyma konsekwentnie przestrzegała zasady powstrzymywania się od odpowiedzi na krytykę literacką czy osobiste przytyki na łamach czasopism (P, s. 106) - dlatego też tym bardziej warte są gruntownego zbadania niedrukowane materiały o charakterze prywatnym (głównie korespondencja), zachowane $\mathrm{z}$ wielkiego archiwum literackiego i rodzinnego Euszczewskich. Według Andrzeja Biernackiego, autora hasła osobowego w Polskim stowniku biograficznym, spora część tych zbiorów spłonęła w czasie II wojny światowej w Bibliotece Ordynacji Krasińskich w Warszawie; wycinki prasowe znajdują się w zbiorach Instytutu Badań Literackich PAN (materiały z dawnego Archiwum Towarzystwa Literatów i Dziennikarzy Polskich), listy z zesłania przechowuje Muzeum Narodowe (sygn. 23664), zaś tzw. „Czarną Księgę Deotymy” (wycinki prasowe, odbitki korektowe zgromadzone przez Hipolita Skimborowicza) - Muzeum Literatury w Warszawie (za: A. Biernacki, hasło: Euszczerwska Jadwiga, w: Polski stownik biograficzny, op. cit., s. 583). Korespondencja Deotymy z okresu młodości znajduje się w Bibliotece Narodowej, w zbiorze listów różnych osób z lat 1832-1864, sygn. III. 5992 (zob. I. Woszczak, Deotyma (Jadwiga Euszczewska) w witrynie artystycznej ewaluacji..., op. cit., s. 82).

5 Deotyma wspomina o wieczorach, liczących niekiedy dwieście, a nawet trzysta osób (P, s. 167). Ta informacja rzuca niejakie światło na często powtarzane zarzuty skąpstwa „wieszczki”, oferującej swoim gościom głównie strawę duchową, zaś jako poczęstunek jedynie „lawę” albo „poncz” (letnią wodę z esencją ponczową) z pierniczkami (S. Podhorska-Okołów, Warszawa mego dzieciństwa, War- 
Szczyt jego popularności przypadł mniej więcej na rok r88ı, kiedy to Deotyma zorganizowała jubileusz swego wiernego admiratora, Antoniego Edwarda Odyńca; śmierć dwóch filarów „czwartków”: Hipolita Skimborowicza w I880 i Odyńca 1885 roku zapoczątkowała ich powolny upadek.

Dla autora szkicu Życie fikcyjne i obrzędowe Deotyma jest typem przeciętnej kobiety sfer zamożnych (wręcz ,arystokratycznych”, a są to „warstwy nie potrzebujące pracować na swoje utrzymanie, nie poczuwające się do obrony jakichkolwiek interesów i przeprowadzania celów w życiu”). Niezdolna do spojrzenia na ową ograniczoną egzystencję z zewnątrz, mimowolnie daje w swoich tekstach doskonałe odbicie „profilu kobiety jej sfery, żyjącej i poruszającej się według form ustanowionych tradycją i modą, ożywiającej je fikcjami religii i sztuki oraz wiedzy, aprobowanymi przez kościóp” ${ }^{\circ}$. Nie odmawiając Łuszczewskiej technicznej sprawności wierszowania, a nawet pewnego talentu, publicysta ostrze swoich zarzutów kieruje przede wszystkim przeciw obecnej w jej dziełach konserwatywnej ideologii, a zwłaszcza sposobowi widzenia świata, odbieranego niejako „z drugiej ręki”, przez pryzmat kontemplacji estetycznej i gromadzenie ogromnego bagażu erudycyjnych drobiazgów, co powoduje, że nie jest zdolna do stworzenia „żadnego rzeczywistego dzieła sztuki":

\I) Umysł Deotymy, nie zważając na cały nawał wrażeń życiowych i teoretycznych, nie przedstawia żadnych śladów stopniowego rozwoju. Zawsze i wszędzie jest odbiciem ech tradycyjnych i ortodoksyjnych pod względem wiary, moralności, nauki, sztuki etc., bez żadnego nawet w swojej sferze udoskonalenia.

2) Wyobraźnia Deotymy zaprzątniętą jest całkowicie nie objawami życiowymi, lecz odgłosami wrażeń, odebranych z dzieł sztuki, przemysłu i nauki, etc.

3) Za jedyną podwalinę, utrzymującą życie społeczne, Deotyma uznaje o b r z ę d, raz ustanowiony i tradycyjnie uznany za „dobry ton”. Sprawiedliwe, słuszne i moralne czyny są to czyny wykonane według wszelkich wymagań „dobrego tonu”.

4) Religia Deotymy jest to wiara w Istotę, ustanawiającą, dopełniającą i korygującą niedokładności szczegółów „dobrego tonu”.

szawa 1958; „podają tylko poncz i czarną kawę”- J. Kopeć, „Czwartek” u Deotymy, w: eadem, Dziecko dawnej Warszawy, Warszawa 1958, s. 72), „czasem - torty i lody” (Cz. Jankowski, Z czeczotkowej szkatutki. Odgtosy ginacego świata, Wilno 1926, cyt. za: P, s. 201).

6 [B. Białobłocki], Życie fikcyjne i obrzedowe. (Przyczynek do studium nad Deotyma i kierunkiem naszej literatury), cz. I, „Przegląd Tygodniowy” z 10 (22) kwietnia 1883, nr 16, s. 193. 
5) Miłość idealna, nie szatańska, jest to wieczna gra w ciuciubabkę z otwartymi oczami dwojga ludzi różnej płci, z zachowaniem form „dobrego tonu”. Jakaś gonitwa dwojga serc według ustanowionych prawideł.

6) Jedyny użytek z nauki - ożywienie konwersacji.

7) Sztuka nareszcie jest rozkoszą ducha i serc, gdyż pomaga bawić się $\mathrm{w}$ życiu przyjemnie i w dobrym tonie.

Na zasadzie powyższego szumowania twierdzę, że dzieła Deotymy są typem życia fikcyjnego i obrzędowego w pewnej ciasnej sferze. Jako takie, pozostaną one ciekawym dokumentem czasu, ale jak nie wywarły, bo wywrzeć nie mogły, na współczesnych swego wpływu, tak i nie będą miały żadnego życiowego znaczenia dla potomności

Artykuł jest anonimowy, choć w spisie treści całego rocznika został opatrzony kryptonimem Bł., którym podpisywał swoje publikacje na łamach „Przeglądu” Bronisław Białobłocki ${ }^{8}$. Na podstawie hasła w Polskim stowniku biograficznym można stwierdzić, iż w roku 1883 ten publicysta, pochodzący z ubogiej rodziny szlachty zagonowej, miał 22 lata, a za sobą trudny okres studiów w Petersburgu, który zaowocował zdobyciem wiedzy w dziedzinie prawa i sztuk pięknych, bliskimi związkami z ruchem socjalistycznym (środowisko późniejszego „Proletaryatu”) i poważnymi kłopotami ze zdrowiem w rezultacie permanentnego głodowania (co doprowadziło zresztą do jego przedwczesnej śmierci w I888 roku). Wpływowi Białobłockiego jego biograf i przyjaciel, Ludwik Krzywicki, przypisuje zresztą radykalny ton publikacji „Przeglądu Tygodniowego”9. Czy można się zatem dziwić, że dla młodego, zapalczywego dziennikarza o socjalizujących poglądach i trudnej sytuacji materialnej, który do warszawskich salonów raczej nie bywał zapraszany, starsza o pokolenie ,romantyczna wieszczka” Deotyma stanowi w najlepszym razie okaz minionej epoki, słusznie skazany na wymarcie? Jej erudycja wydaje mu się efektem „mozolnych studiów dyletanckich”, religijność jest powierzchowna, kult „dobrych manier” - co najmniej irytujący, umysł - skostniały, osobowość - niezdolna do rozwoju ${ }^{\mathrm{ro}}$, a idealna wizja świata nie ma nic wspólnego z rzeczywistością.

7 Idem, Życie fikcyjne i obrzędowe. (Przyczynek do studium nad Deotyma i kierunkiem naszej literatury), cz. IV, „Przegląd Tygodniowy” z 1 (13) maja 1883, nr 19, s. 232.

8 Stownik pseudonimów pisarzy polskich: XV w. - 1970 r., t. I (A-I), oprac. zespół pod red. E. Jankowskiego [i D. Świerczyńskiej], Wrocław 1994, s. 273.

9 L. Krzywicki, hasło: Biatobtocki Bronistaw, w: Polski stownik biograficzny, t. II, Kraków 1936, s. 12-13.

10 Warto tu zacytować następujący charakterystyczny fragment, odwołujący się aluzyjnie do kilkunastomiesięcznego pobytu Łuszczewskiej w Rosji, gdzie towarzyszyła zesłanemu ojcu: „Z krótkiej tej biografii poetki widzimy, że otrzymawszy staranne wychowanie w domu rodziców i nie mając sposobności zebrania w nim żadnego zasobu życiowych obserwacyj, zaczęła zawód pisarski. Lecz 
Budując konsekwentny obraz swojej przeciwniczki dla potrzeb polemiki z „warstwami nie potrzebującymi pracować na swoje utrzymanie”, młody pozytywista automatycznie utożsamia poglądy jej bohaterów powieściowych z sądami samej autorki i absolutnie nie dostrzega na przykład lekkiej ironii, wyraźnie obecnej w przywoływanych scenach z „życia salonowego" ${ }^{\text {II }}$. Samoświadomość i dystans z założenia nie mogą bowiem być dostępne rozpieszczonej istocie żyjącej pod kloszem, która odbiera świat wyłącznie przez pryzmat lektur, zaś niedostatki realnych doświadczeń kompensuje sobie naiwnym fantazjowaniem, godnym podlotka ${ }^{\mathrm{I} 2}$. Warto jednak zadać pytanie - czy portret „królowej ideału”, niegdysiejszej genialnej improwizatorki, na łamach tego akurat pisma w ogóle mógłby wyglądać inaczej?

\section{IMPROWIZACJA I KOMPROMITACJA}

Ostra krytyka staje się jednak udziałem Deotymy niemal od chwili debiutu. Co szczególnie interesujące, częstokroć wygłaszają ją te same osoby, które wcześniej rozpływały się w zachwytach nad geniuszem improwizatorskim młodej wieszczki! Taką zaskakującą „zmianę frontu” można zauważyć co najmniej w kilku przypadkach, nie tylko autorów minorum gentium (czy też dziś uznawanych za pomniejszych, lecz podówczas bardzo wpływowych), ale i pierwszych piór literatury, by przywołać choćby Zygmunta Krasińskiego. Z listu do Andrzeja Edwarda Koźmiana (marzec I853 roku) można przytoczyć takie słowa: „młoda siedemnastoletnia dziewica

same okoliczności rzuciły autorkę na obczyznę, zmusiły do przyjęcia całej masy zupełnie nowych wrażeń i zastanawiania się nad szeregiem ściśle życiowych zagadnień. Naturalną byłoby przeto rzeczą oczekiwać stanowczych w niej zmian, nie tylko w sferze przedmiotów opisywanych, lecz nawet w metodzie, w stylu, ideach, jako wynik rozszerzenia widnokręgu umysłowego. Jeżeli zaś wypadki odbijają się od duszy jak groch od ściany, nie zostawiając najmniejszych śladów, to bezsprzecznie można wnieść, iż dusza takowa wspaniałą jest w żelaznej swej mocy, lub, co prawdopodobn i j j z e, że dusza takowa niezdolna jest wcale rozwijać się według normalnych praw życia [wyróżn. A. B.]”. ([B. Białobłocki], Życie fikcyjne i obrzędowe. (Przyczynek do studium nad Deotyma i kierunkiem naszej literatury), cz. I, „Przegląd Tygodniowy” z 10 (22) kwietnia 1883, nr 16, s. 193).

11 W tym miejscu można wspomnieć choćby przytaczane najzupełniej serio z powieści $\mathrm{Na}$ rozdrożu uwagi o nauce z Jockey-Clubu, „której nie mogło brakować w dyplomie modnego młodzieńca”, czy o „cierniowym życiu panien” w salonie, od których ucieka męska młodzież: „A jednak trudno powiedzieć, aby wszystkie były tępe i ograniczone, bo przecież z tych samych panien wyrastają mężatki, za których towarzystwem później ta sama młodzież goni”(ibidem).

12 Porównując miłość rybaka i bogini Wisławy z 1858 roku z romansem współczesnym (Na rozdrożu) z 1877 roku Białobłocki pisze: „Na mnie obie historie miłośne obok uderzającego podobieństwa robią jeszcze wrażenie uczuć nieodczutych, obrazów wymarzonych, pokombinowanych z tego, co się czytało, słyszało i co by się chciało samej odczuć, widzieć, doznawać...” (idem, Życie fikcyjne i obrzędowe. (Przyczynek do studium nad Deotyma i kierunkiem naszej literatury), cz. II, „Przegląd Tygodniowy” z 17 (29) kwietnia 1883, nr 17, s. 209). 
cudownym sybilijnym natchnieniem mędrków i niedowiarków zachwyca"r3 - ale tenże sam Koźmian odnotowuje niechętną postawę poety: „zowie to publiczne występowanie une prostitution ducha" "'. Etap fascynacji przechodzącej w zjadliwą krytykę mają za sobą regularni goście salonu państwa Łuszczewskich: Wacław Szymanowski i Aleksander Niewiarowski, którzy początkowe egzaltowane zachwyty rychło zamieniają w niepodpisane krytyki prasowe, a także mniej czy bardziej dowcipne parodie jej improwizacji - wygłaszane zresztą przez dłuższy czas za plecami gościnnych, a nieświadomych gospodarzy. Nazwiska te przywołuje Izabela Woszczak, zauważając: „Intrygujący był fakt, że jej najbardziej zjadliwymi prześmiewcami stawała się część niedawnych wielbicieli - jedni występowali otwarcie przeciwko dawnemu bożyszczu, inni, zasłonięci pancerzem obłudy, nadal uczęszczali na poniedziałki, oficjalnie doceniając jej pracę, nieoficjalnie zaś, anonimowo, ściągając wieszczkę w błoto paszkwilu” ${ }^{\text {I5 }}$. (I nie jest to określenie przesadne - Niewiarowski na przykład w latach I854-I857 publikuje w „Gazecie Warszawskiej” utrzymane w przypochlebnym tonie sprawozdania i recenzje z poniedziałkowych improwizacji, a równocześnie wydaje w 1855 roku szkic obyczajowy Galeria panien na wydaniu, w którym pod postacią panny nr 4, zwanej Literatką, zamieszcza karykaturalną sylwetkę Deotymy). Podobną postawę zaprezentował Henryk Rzewuski, pozwalając sobie w prywatnych rozmowach na uwagi tak ordynarne, że obudziły oburzenie Franciszka Wężyka (P, s. 229). Ten ostatni i Kajetan Koźmian należeli do opiniotwórczych autorytetów, „mędrców-klasyków”, którzy sami również od początkowej łaskawości i wielkich nadziei, pokładanych we wschodzącej gwieździe polskiej poezji, przeszli do surowych krytyk, dotyczących przede wszystkim rozmieniania na drobne talentu, „zniweczonego daru bożego" ${ }^{\prime 6}$, złożonego w ofierze próżności i płytkiemu życiu salonowemu. Ogromne zróżnicowanie żywionych emocji: od zafascynowania niezwykłym zjawiskiem i pewnej snobistycznej przyjemności uczestniczenia w przeżyciu dostępnym jedynie wybrańcom (a dotyczy to nie tylko samego aktu improwizacji, ale i wizyty w salonie Euszczewskich, a następnie przyjęć u samej Deotymy) do rozczarowania i kpiny można zaobserwować również w ostatnich dekadach jej życia na przykładzie Artura Oppmana

13 Za: W. Weintraub, hasło: Improwizacja, w: Stownik literatury polskiej XIX wieku, red. J. Bachórz i A. Kowalczykowa, Wrocław-Warszawa-Kraków 1991, s. 364.

14 Ibidem.

15 I. Woszczak, Deotyma (Jadwiga Euszczerwska) w witrynie artystycznej erwaluacji.., op. cit., s. 56.

16 Tego określenia używa w liście z 1885 roku Andrzej Edward Koźmian, cyt. za: I. Woszczak, Sekrety i porywy późnej twórczości..., op. cit., s. 107. Autorka zwraca tu uwagę na fakt, że ostre w tonie krytyki mogły być wywołane tyleż rzetelną oceną twórczości Jadwigi Łuszczewskiej, dokonaną z nieco szerszej perspektywy czasowej, co rozgoryczeniem obu autorytetów, ustawiających się wszak początkowo na pozycji nauczycieli i protektorów, których mądre rady zostały przez lekkomyślną wieszczkę zlekceważone (passim). 
(Or-Ota). We wspomnieniach Jadwigi Kopeć wyczekiwany „czwartek u Deotymy” rozczarowany „dworską etykietą” poeta podsumowuje słowami: „Byłem pierwszy i ostatni raz. [...] Jakiś owczy pęd”, „To wypociny, nie talent!"'7. Na marginesie warto jednak zaznaczyć, że we własnym tekście wspomnieniowym, opublikowanym już po śmierci Łuszczewskiej, Oppman rysuje znacznie bardziej uładzony i pełen rewerencji obraz swoich licznych wizyt, poświęcając zmarłej poetce wiele ciepłych słów i usprawiedliwiając jej „monarsze fantazje” ${ }^{18}$.

Badacze literatury zaliczają z reguły Deotymę do grona epigonów romantyzmu (czyni tak już Wilhelm Feldman na kartach Wspótczesnej literatury polskiej I864$I 823^{\mathrm{I}}$ ), jako autorkę powieści historycznych, uznając ją za „reprezentantkę formacji niewiarygodnie archaicznej” ${ }^{20}$, „dziwaczną poetkę i deklamatorkę" ${ }^{21}$, żywy dowód egzaltacji uczuciowej i osobliwych upodobań poprzednich pokoleń. Zdarzają się oceny jeszcze mniej łaskawe, jak na przykład tekst Bogdana Zakrzewskiego z I994 roku, poświęcony atrybucji wiersza Do Deotymy z powodu jej improwizacyj, przez pewien czas przypisywanego Mickiewiczowi ${ }^{22}$. Większość edytorów zgadza się obecnie, że to wątpliwe mickiewiczianum, którym chlubiła się Deotyma, wydrukowane w „Tygodniku Petersburskim” w I953 roku pod kryptonimem „M.” wyszło spod pióra jego redaktora, Józefa Emanuela Przecławskiego (taką informację podaje też Polski stownik biograficzny w biogramie Łuszczewskiej). Literaturoznawca proponuje inną hipotezę, twierdząc bardzo stanowczo (choć na podstawie co najmniej wątłych przesłanek), że wiersz napisała „wieszczka” sama do siebie pod dyktando apodyktycznej matki-impresaria, wydrukowała go pod świadomie mylącym, przejrzystym kryptonimem i przez całe życie $z$ uporem podtrzymywała tę mistyfikację. Bardziej prawdopodobne wydaje się, że wiersz, jeśli nawet jego autorem nie był Przecławski (sygnujący swe teksty pseudonimem Micrus), to powstał w kręgu towarzyskim państwa Łuszczewskich, a nobilitująca informacja była przez poetkę powtarzana raczej w dobrej wierze - ale w kontekście przemian kulturowych znacznie ciekawsza niż wywody zmierzające do stuprocentowo pewnej atrybucji tekstu wydaje się postawa mickiewiczologa, pełna nieskrywanej niechęci, a wręcz

17 J. Kopeć, op. cit., s. 74.

18 A. Oppman, Czwartki u Deotymy, cyt. za: P, s. 205-207.

19 W. Feldman, Wspótczesna literatura polska 1864-1823, Warszawa 1923, s. 30-31.

20 Pisze tak Julian Krzyżanowski w recenzji kolejnego wydania Panienki z okienka w 1939 roku, stwierdzając wręcz, że po Sienkiewiczu i Żeromskim pozycję tę „należałoby zapomnieć, a nie wskrzeszać i zalecać jako lekturę dla młodzieży" (J. Krzyżanowski, Dobre chęci Deotymy (przedruk), w: idem, W kręgu wielkich realistów, Kraków 1962 , s. 207).

21 K. Tokarzówna, Odwiedziny „wieszczki”, w: Literackie przystanki nad Warta, red. Z. Szweykowski, Poznań 1962, s. 386.

22 B. Zakrzewski, „Istotnie, Bóg dat Polsce genialna poetkę”. Rzecz o mickiewiczowskim falsyfikacie, w: idem, „Spowiednicy” Mickiewicza i Fredry oraz inne eseje, Wrocław 1994. 
wzgardy dla Jadwigi Łuszczewskiej i jej poezji, której przyrównywanie do Mickiewicza zakrawa dla niego wręcz na bluźnierstwo. Pomysł, że słowa „Istotnie, Bóg dał Polsce genialną poetkę", które padły w rozmowie Józefa Bohdana Zaleskiego z Mickiewiczem ${ }^{23}$, mogłyby wyjść $\mathrm{z}$ ust arcypoety, to po prostu obelga dla jego gustu („Aż dziw bierze i przerażenie”, „kompromitujące poetę quasi-współzachwyty”, „niezamierzona wartość... humorystyczna” takiego cytatu ${ }^{24}$ ). Na początku tekstu, przed przedstawieniem i przeanalizowaniem materiału dowodowego (który sam nazywa „poszlakami”), Zakrzewski twierdzi stanowczo, że autorstwo wieszcza jest wykluczone, ponieważ „Ani Mickiewicz, ani Krasiński nie splamili się takimi hołdami” ${ }^{25}$, wymuszanymi przez sprytnie organizujące sobie klakę salonową panie Łuszczewskie. Owo oskarżenie o falsyfikat ku własnej chwale wydaje się bardzo dobitnie ilustrować zjawisko drastycznych przemian hierarchii literackich i ocen na przestrzeni dziesięcioleci - jeśli bowiem wiersz pochwalny dla Deotymy został przypisany Mickiewiczowi, to znaczy, że w momencie, w którym powstał, uważano to za rzecz możliwą, a nie kompromitującą i nieprawdopodobną. „Dziewica-poetessa" w latach pięćdziesiątych XIX wieku nie była zatem postrzegana jako groteskowa karykatura prawdziwego wieszcza, a jej „przymierzania” własnych planów poetyckich do dzieł już stworzonych przez uwielbianego poetę bynajmniej nie traktowano w szerokim kręgu wielbicieli jako szokującego uroszczenia.

Zdaje się, że temperatura sporów o Deotymę i ocenę jej dorobku byłaby znacznie niższa, gdyby poetka nie posiadała daru improwizatorskiego. Wiktor Weintraub zwraca uwagę na nader interesujący dualizm pojęcia „improwizacja” w kulturze romantycznej. Otóż o ile drukowany utwór poetycki, powstały pod wpływem natchnienia (co zaznaczano takim „komentarzem okolicznościowym” w tytule lub podtytule), był wysoko ceniony, o tyle istniała również ,improwizacja” znacznie mniej wzniosła, a bardziej ludyczna, która zyskała sobie popularność na przełomie XVIII i XIX wieku, głównie we Włoszech (gdzie jej tradycje sięgały jeszcze późnego średniowiecza). „Improwizacjami” nazywano publiczne popisy (zazwyczaj płatne - jak się wydaje, to szczegół nie bez znaczenia!) układania wierszy bez uprzedniego przygotowania na tematy rzucane przez słuchaczy. Improwizacja miała tu charakter salonowej rozrywki, nie mistycznego przeżycia, zaś improwizator był raczej zręcznym prestidigitatorem, nierzadko po prostu zarabiającym w ten sposób na życie ${ }^{26}$. Literackie portrety poetów-improwizatorów można znaleźć

23 Korespondencja Józefa Bohdana Zaleskiego, wyd. D. Zaleski, t. 2, Lwów 1901, s. 206, cyt. za: B. Zakrzewski, op. cit., s. 126.

24 B. Zakrzewski, op. cit., passim.

25 Ibidem, s. 129. Notabene, z grona wielkich poetów „splamił się” na przykład Cyprian Kamil Norwid, pisząc w grudniu 1860 roku wiersz do młodej poetki.

26 W. Weintraub, op. cit., s. 363-364. 
u pani de Staël (Korynna I807), Hansa Christiana Andersena (Improwizator I835) czy Aleksandra Puszkina (Noce egipskie 1837). Utożsamienie publicznego występu $\mathrm{z}$ darem profetycznym dokonało się właściwie w przypadku jednego jedynego wybitnego poety romantycznego - był nim właśnie Adam Mickiewicz ${ }^{27}$. Bulwersujące dziś postrzeganie Deotymy jako „spadkobierczyni” wieszcza i niezwykła, powszechna fascynacja osobliwym talentem młodej poetki wydają się w pewien sposób charakterystyczne dla polskich odbiorców lat pięćdziesiątych XIX wieku, którym Mickiewicz narzucił niejako tę wzniosłą optykę improwizacji. Można postawić tezę, że dlatego też z Jadwigą Euszczewską wiązano w momencie jej debiutu ogromne oczekiwania (którym zapewnie nikt nie byłby w stanie sprostać), a fala kpin i głębia rozczarowania okazują się wprost proporcjonalne do wielkości zawiedzionych nadziei. To, co miało być wzniosłe, na dłuższą metę okazało się śmieszne; świątynia zamieniła się zgoła w pokaz cyrkowy, uczestnicy spotkań nie przeżyli duchowego odrodzenia, jedynie snobistyczny wieczór w modnym salonie. Po zaspokojeniu ciekawości wielu z nich zdaje się czuć zażenowanie, którego źródłem jest nie tyle sama „wieszczka”, co własna uległość wobec wszechwładnej towarzyskiej mody.

Ten dualizm improwizacji jako specyficznego zjawiska kulturowego dobrze oddaje opis wrażeń sceptycznie nastawionej do „genialnej poetki” Bibianny Moraczewskiej, która notuje w swoim dzienniku wspomnienia z wizyty u znajomych w Poznaniu 24 września 1856 roku, kiedy to udało jej się zobaczyć ów fenomen. Opis poświęca dużo miejsca zachowaniu panny Łuszczewskiej, określonej jako rozmówczyni mianem sztywnej i „wcale niesympatycznej”, jej przeciętnej powierzchowności („tłuściutka i szerokawa, wzrostu średniego blondynka, z grubawymi rysami, a gdzie brwi ani znaku. $Z$ tym wszystkim dość ładna”28), strojowi, programowi wieczoru, na który złożyło się czytanie kilku dawniejszych utworów oraz clou-improwizacji na temat legendy Kontusik-Jezusik, odebranej przez słuchaczkę jako deklamacja ,jakby w śnie magnetycznym”. Doświadczenie Moraczewskiej dalekie jest od egzaltowanych zachwytów i duchowych wstrząsów - trzeźwa Wielkopolanka podsumowuje w bardzo charakterystyczny sposób: „Cały ten wieczór przepędziłam mile. [...] kontenta jestem, że tę osobliwość widziałam, ale zawsze w tej improwizacji jest trochę łamanych sztuk" ${ }^{\prime 2}$.

Sama Deotyma na kartach pamiętnika również daje wyraźne świadectwo śladów tej drugiej, cokolwiek rozrywkowej proweniencji swoich improwizacji. Wspomina

27 Ibidem, s. 363.

28 B. Moraczewska, Dziennik Bibianny Moraczewskiej, Poznań 1911, cyt. za: K. Tokarzówna, Odwiedziny „wieszczki”, op. cit., s. 379. 
o widzianym w salonie rodziców „cudownym człowieku”, starozakonnym profesorze Dänemarcku, który na wieczorze 23 stycznia I843 roku dał pokaz swych umiejętności, podając na wyrywki treść żądanych wersetów z Pisma Świętego. Na ośmioletniej dziewczynce ogromne wrażenie wywarło malujące się na twarzy Wundermanna „bolesne wysilenie”, dowodzące „szalonej pracy pamięci” (P, s. 47). Swoje własne improwizacje widziała w nieco podobnych kategoriach „Zadania” i „obowiązku”, protestując przeciw nazywaniu ich „szałem poetyckim” czy „odurzeniem”, przeciwnie, przeciwstawiając odcięcie się od rozpraszających bodźców zewnętrznych w pełni świadomemu i kontrolowanemu stanowi „wyższej jawy”, rozbudzenia i koncentracji władz umysłowych. Polemizując z często przytaczaną na jej temat opinią Zygmunta Krasińskiego („To nie dziewczę mówi, ale przez dziewczę mówi”), pisała:

》S Słowa te brzmią ładnie, szkoda tylko, że zawierają fałszywe pojęcie.

Osoba improwizująca to nie żadne medium, to nie narzędzie, to władca narzędzia, to istota najzupełniej przytomna, przytomniejsza niż ci, co ją słuchają, bo taka potężna praca wymaga kryształowej przytomności umysłu. [...]

Oj, to najważniejsza rada. Jedna chwila roztargnienia, a już po całym czarze. Niech osoba improwizująca spojrzy uważnie na kogo ze słuchaczy lub nawet na jaki obraz albo mebel, juz zaczyna sobie przypominać: „Aha - to ja jestem tu a tu..., mówię przed tym i owym, a o czym to ja mówię?..." I przez czas, kiedy to myśli, traci wątek improwizacji, nie wie, co już powiedziała, nie wie, na czym stanęła; tymczasem chwile biegną, milczenie trwa, słuchacze dziwią się i zaczynają chrząkać... i wszystko może skończyć się na haniebnym fiasco.

[...]

$Z$ tego wszystkiego, co powiadam, pokazuje się, że improwizowanie jest właściwie przyspieszonym procesem tworzenia. Jest to pociąg „błyskawiczny”, w którym przemawiający przebywa tę sama drogę, co piszący, tylko przebywa ją z nierównie większą, lotnością i... większym niebezpieczeństwem (P, s. 98-99).

\section{4. „Sprawa Deotymy”}

Sensacyjny zarzut tajemniczej współpracy z carskim rządem, za który poetka miała pobierać regularną pensję, pojawił się po raz pierwszy w obszernym streszczeniu Wspomnień z mojego życia Felicjana Faleńskiego, dokonanym przez wydawcę, 
Wiktora Przecławskiego ${ }^{30}$. Faleński, zmarły w I9Io roku, przed śmiercią przekazał swoje pamiętniki do biblioteki Branickich w Wilanowie - Przecławski korzystał z nich, przygotowując swoją monografię Medard Felicjan Faleński, żywot i dzieta $(\mathrm{I} 922)^{3 \mathrm{I}}$. Bliższa analiza samego tekstu wspomnień - wydrukowanego w całości dopiero w I964 roku - pokazuje, że wydawca mocno się zagalopował, obiecując na poparcie swych twierdzeń opublikowanie dowodów, jakoby odkrytych w „tajnych archiwach warszawskich”. W istocie zmarły poeta we fragmentach poświęconych Deotymie stawiał prowokacyjne pytania (na przykład: dlaczego poetessa „zaraz po powrocie" z zesłania składała wizyty na Zamku u krwawego namiestnika Berga, którego w dodatku „wiecznie” zapraszała na swoje wieczory?), nierzadko jednak posuwał się do manipulowania faktami ${ }^{32}$ i przez odpowiednie naświetlenie powszechnie znanych informacji tworzył atmosferę podejrzliwości i insynuacji („Nadskakiwania te [...] uwieńczone zostały dożywotnią pensją I50o rubli, którą wieszczka (równie jak i Odyniec - trudno wiedzieć, za co) od rządu pobiera”33). Jeszcze w czasie I wojny światowej z oburzeniem ripostował na ten temat na łamach prasy wierny bywalec salonu Deotymy, Aleksander Kraushar (w I9I7 roku), publikując rozszerzoną wersję odpowiedzi w szkicu Deotyma. Tragedia pozgonna żywota i twórczości poetki, zamieszczonym w książce Polki twórcze czasów nowszych (1929). Tajemnicza „pensja” okazała się po prostu rentą po ojcu, wieloletnim carskim kamerjunkrze. Wacław Łuszczewski zrzekł się tytułu w demonstracyjnym geście w gorącym roku 1862 (za co zresztą został skazany na kilkunastomiesięczne zesłanie do Jadrynia, później Symbirska i Czembaru, na którym dobrowolnie towarzyszyła mu córka). Po ułaskawieniu i zezwoleniu na powrót do Warszawy przywrócono mu rządową pensję razem z innym prawami. Renta Deotymy, wbrew insynuacjom zgorzkniałego Faleńskiego, nie była żadną tajemnicą, skoro ogłoszono tę informację publicznie w rządowej gazecie, sankcjonując w ten sposób jej prawo do pobierania pensji ${ }^{34}$, czego nigdy nie robiono w przypadku nagród dla carskich agentów. ( $\mathrm{Na}$ marginesie warto zaznaczyć, że takie samo „wynagrodzenie” rządowe po ojcu,

30 Ich fragmenty drukowano w „Przewodniku Naukowym i Literackim” (1914, z. 5), a następnie w „Nowym Przeglądzie Literatury i Sztuki” (1921, t. 1, nr 1-3, s. 310-327).

31 M. Tyrowicz, hasło: Faleński Felicjan, w: Polski stownik biograficzny, t. 6, Kraków 1946, s. 351.

32 Na przykład udokumentowano tylko jedno zaproszenie do salonu Deotymy dla Berga, wystosowane w 1871 roku wobec podejrzeń zaborcy o „nieprawomyślność” tych spotkań. Wizyta się odbyła, choć w napiętej atmosferze, podejrzenia zostały rozwiane, a towarzystwo warszawskie potraktowało incydent ze zrozumieniem, nigdy nie czyniąc z tego powodu Łuszczewskiej wyrzutów.

33 F. Faleński, Wspomnienia z mojego życia, wyd. i oprac. J. Rudnicka, w: Miscellanea z pogranicza XIX i XX wieku, Wrocław 1964 (Archiwum Literackie VIII); cyt. za: P., s. 191.

34 Kraushar omawia te kwestie, powołując się na artykuł Kazimierza Bartoszewicza Easka carska w sprawie Deotymy („Rzeczypospolita” nr 143 z 27 maja 1922 r.); zob. A. Kraushar, Deotyma. Tragedia pozgonna żywota i twórczości poetki, w: idem, Polki twórcze czasów nowwszych, Warszawa 1929, s. 27-28. 
niesławnej pamięci sędzim Józefie Faleńskim, pobierał sam Faleński, a także jego żona, Maria z Trębickich, córka generała, zabitego omyłkowo przez powstańców w czasie Nocy Listopadowej). „Sprawa Deotymy” okazała się zatem humbugiem, pomówieniem rzuconym przez poetę, znanego ze swej mizantropii i szczególnego wyczulenia (choćby z racji „obciążenia rodzinnego”) na kwestie zdrady i patriotyzmu, które dochodziło u niego niemal do granic obsesji. Niechęć do Deotymy (której portret jest na kartach Wspomnień z mojego życia bardzo niekonsekwentny, od przyznawania „nadzwyczajnego daru” i zdolności do tworzenia „pindarycznych arcydzieł”, po oskarżenia o mierność umysłu i „zawróconą głowę”) można za Krausharem wytłumaczyć w sposób dość przekonujący, choć korzystający w niegodnych argumentów ad personam. Niewątpliwie utalentowany Faleński nigdy nie cieszył się szczególnym uznaniem opiniotwórczej prasy ani popularnością wśród czytelników, stąd też w jego uwagach na temat szczęśliwszych - chwalonych i opłacanych - autorów można znaleźć niemało żółci. Co przy tym charakterystyczne, najostrzejsze komentarze dotyczą okresu, w którym oboje Faleńscy, ongiś goście salonu Niny Łuszczewskiej, nie utrzymywali z Jadwigą Łuszczewską żadnych kontaktów towarzyskich. Nawiązali je powtórnie dopiero wtedy, gdy „czwartki” Deotymy miały już za sobą lata największej świetności, a schorowaną, pozbawioną licznego „dworu pochlebców" wieszczkę można było traktować nie z podziwem i atencją, lecz ze współczuciem ${ }^{35}$.

\section{WYBRANKA CZY OFIARA?}

Wokól „wieszczki Deotymy” narosło bardzo wiele barwnych opowieści, które po bliższym przeanalizowaniu okazują się przekazami „z drugiej ręki” (jak choćby w przypadku relacji Or-Ota, opinii Mickiewicza czy Kraszewskiego), a niekiedy po prostu plotkami. Charakter takiej właśnie anegdoty ma „późna (ale psychologicznie bardzo wiarygodna tradycja) ${ }^{36}$, powtarzająca wypowiedź przypisywaną Ninie Łuszczewskiej, która postawiła młodszą córkę przed koniecznością dokonania życiowego wyboru. Juliusz Wiktor Gomulicki, wydawca pamiętnika Deotymy,

35 Pamiętnikarz ujmuje to tymi słowy: „Śmierć Skimborowicza, a następnie Odyńca najzupełniejszy przewrót w przyjęciach Deotymy sprowadziła. Zawalenie się tych dwóch filarów tronu na dobre jej wyszło. Zeskromniała, z wolna kółko dworaków się rozpierzchło i nareszcie sama szukać poczęła dawnych zaniedbanych stosunków. Jakoż na obchodzie jubileuszu Zachariasiewicza zbliżyła się do nas i po staremu szczerze prosiła o powrócenie do dawnej przyjaźni. Nawiązało się to tym łatwiej, ile że wszelki nastrój uroczysty jej salonu bezpowrotnie w mgłę się rozwiał" (F. Faleński, op. cit., cyt. za: P, s. 194).

36 J. W. Gomulicki, O salonie literackim dwóch pań Łuszczerwskich [wstęp], w: P, s. 25. 
nie daje w tym miejscu żadnego odsyłacza źródłowego, a rzekomy cytat opatruje zastrzeżeniem:

》 [matka - A. B.] miała się do niej odezwać w takie mniej więcej słowa:

- Jeżeli chcesz zostać poetką, musisz na zawsze wyrzec się życia przeciętnej kobiety, małżeństwa i macierzyństwa. A jeśli chcesz tańczyć na balach, mieć konkurentów i wyjść za mąż, mowy nie ma o poezji. Muzy są zazdrosne i nie dzielą się z nikim. Wybieraj!37

Cytat zdaje się zbyt efektowny, aby był prawdziwy - i zbyt dobrze pasuje do stworzonego we wstępie obrazu rodziny wręcz „opętanej salonem”, w której próżność zabiła wszelkie inne uczucia. Sama scena dramatycznego wyboru osiemnastolatki bardzo przypomina rozterki mitycznych bohaterów w rodzaju Achillesa czy Heraklesa, za młodu stających na rozstajnych drogach. Ujmowany w ten sposób wybór Łuszczewskiej, dokonany pod presją despotycznej matki, już przez jej współczesnych krytyków był postrzegany jako tragiczny błąd, odstąpienie od „prawdziwego powołania” kobiety i zmarnowanie swoich szans na pełne, dojrzałe, szczęśliwe życie. Co bardzo charakterystyczne, w komentarzach powstałych na przestrzeni ponad stu lat odbija się dość stereotypowa i - bądźmy szczerzy - raczej patriarchalna wizja owej „pełni egzystencji”. Wyznacza ona kobiecie jedyne właściwe miejsce jako dopełnienie mężczyzny, a jej dojrzałość psychiczną i doświadczenie życiowe utożsamia niemal wyłącznie ze sferą erotyki i emocji. Warto tu przytoczyć bardzo charakterystyczne stwierdzenie dziewiętnastowiecznego bywalca salonów, opatrzone niemniej interesującym komentarzem dwudziestowiecznego biografa:

》 [...] Roger Raczyński wygrzmiał kiedyś zjadliwą diatrybę przeciw poetce i utrzymywał, że „chcąc, aby Deotyma pisała piękne wiersze, potrzeba jej uczucia, którego nie ma; że na to trzeba, żeby się rozkochała w młodym chłopcu i poszła za niego, żeby on ją traktował comme on le fait avec une princesse du sang ['niby księżniczkę krwi'], to jest, żeby okładał cybuchem, a wtenczas wywiążą się w niej uczucia i prawdziwa poezja obudzi”.

37 Ibidem. Badacz komentuje następnie: „Gdyby młoda improwizatorka mniej kochała swoich rodziców, gdyby była bardziej samodzielna, a mniej próżna, gdyby miała więcej odwagi, a mniej uległości, gdyby miała trochę więcej doświadczenia, a mniej bojaźliwości - to by zapewne wybrała życie, nie zaś ów dziwny jednoosobowy teatr, miłość, nie zaś natrętny podziw widzów panopticum, własną rodzinę, nie zaś krąg ludzi obcych, którzy zastąpili jej z czasem wszystkich bliskich-odeszłych” (ibidem). 
Recepta, trzeba przyznać, osobliwa, ale kto wie, czy przypadkiem nie słuszna [wyróżn. A. B.].I w przypadku Deotymy-poetki i w przypadku Deotymy-kobiety ${ }^{38}$.

Autorzy krytycznych uwag o „toksycznej rodzinie” Łuszczewskich, zdominowanej przez salonowe ambicje pani Niny, które zrujnowały Jadwigę, w zastanawiający sposób bagatelizują lub pomijają pewien istotny fakt biograficzny - otóż były dwie panny Łuszczewskie. Jadwiga miała o pięć lat starszą siostrę, Kazimierę, która zdecydowała się na zupełnie inny, właśnie tradycyjny model życia. Wychowywana podobnie oryginalnymi metodami jak siostra, również była utalentowana literacko (choć o jej dorobku trudno się wypowiadać - archiwum wydawanego przez wiele lat przez dziewczęta domowego pisma „Pszczółka” spłonęło w Warszawie w 1944 roku, zaś jedyną drukowaną spuściznę stanowią Poezje Jolanty, opublikowane w Poznaniu w I862 roku, na rok przed jej śmiercią). W i849 roku wyszła za mąż za Antoniego Komierowskiego, właściciela majątku Śleżany, urodziła kilkoro dzieci, z których w źródłach wzmiankowany jest wyłącznie syn, Jan Wacław Komierowski, poeta pisujący pod pseudonimem Wacław Pomian (P, s. 227). W Polskim stowniku biograficznym Kazimiera wspominana jest wyłącznie w hasłach osobowych dotyczących bardziej znanych krewnych, jako córka Wacława Łuszczewskiego i Niny Łuszczewskiej z Żółtowskich oraz matka Wacława Pomiana. Nie udało się odnaleźć żadnych bliższych wiadomości na temat jej córek - można jedynie wnioskować, że były dwie, skoro Jadwiga pisze, że po śmierci szwagra przygarniała w swoim warszawskim mieszkaniu „to jedną, to drugą panienkę" (P, s. I5I). Nie pozostawiła jednak ani wzmianek o ich losach, ani nawet nie odnotowała imion.

Młoda Deotyma miała więc w najbliższej rodzinie gotową wizję skutków odmiennego wyboru, który miałby zaowocować życiem szczęśliwym i spełnionym, godnym pozazdroszczenia. W swoim pamiętniku z I897 roku wypowiada się jednak o losach siostry w następujący sposób:

\} \quad \text { pisała prześliczne wiersze o treści marzącej a wzniosłej, o formie } krzepkiej a wykwintnej [...].

Zbiór jej poezji wyszedł później w Poznaniu, pod pseudonimem Jolanty. Wszystkie one są piękne, jednak może najpiękniejszymi są pierwsze, te, które pisała jeszcze za dni panieńskich, pod mądrym kierunkiem rodzicielskim; dłużej pod tym kierunkiem zostawiona, byłaby pewnie doszła bardzo wysoko. Ale okoliczności wypadły inaczej; zamążpójście, zmiana otoczenia, liczna dziatwa i zgon przedwczesny 
[w wieku 35 lat - A. B.], nie pozwoliły jej się rozwinąć w pełni. A szkoda, bo to był talent rzeczywisty, z cechą sobie tylko właściwą, znikąd nie naśladowaną (P, s. 85).

Można oczywiście widzieć w tych słowach, pisanych z perspektywy lat, jedynie racjonalizację powziętej decyzji, która pozwala autorce wspomnień obronić przekonanie o celu i sensowności własnej egzystencji. Możliwa jest jednak również inna interpretacja - mamy tu do czynienia z odmienną od powszechnie akceptowanej, osobistą hierarchią wartości, która zupełnie inaczej ocenia "pełnię” i „brak”, „poświęcenie” $\mathrm{i}$ „zmarnowanie”. Rozwój talentu artystycznego i życie rodzinne w myśl dziewiętnastowiecznych popularnych przekonań dla kobiety nie były możliwe do połączenia. Postawienie przez siostrę na pierwszym miejscu rodziny przez Deotymę zostaje podsumowane bardzo dobitnie: „A szkoda!”.

W poezji i prozie młodej Łuszczewskiej brak było wątków erotycznych i politycznych, tych tematów nie poruszano też w rozmowach, prowadzonych w jej salonie. Być może stąd właśnie bierze się bardzo szczególny motyw, który można zauważyć w ocenach twórczości i postaci autorki - gdy była młoda, postrzegano ją jako „stare dziecko", którego powaga i erudycja ma w sobie coś zatrważającego (na przykład Krasiński, wedle przekazu Andrzeja Edwarda Koźmiana w styczniu I853 roku miał się o niej wyrazić: „Goethe w szesnastu latach to coś strasznego"39), po latach widziano zaś w szacownej matronie „wieczną dziewczynkę”. O „wiecznym dzieciństwie poetki” pisze Gomulicki, na dowód przywołując ozdobną laurkę z wierszowanymi podziękowaniami od Hedwigi-Deotymy („Dziękują Ci na wyścigi / Nie jedna, lecz dwie Hedwigi!"), jaką otrzymał jego ojciec za ciepłe słowa o Panience z okienka ${ }^{40}$. Niewykluczone, że w takich samych kategoriach widziano zabawę w „królową ideału” i jej dwór w latach świetności spotkań czwartkowych. Pod piórem oceniających ją mężczyzn Łuszczewska właściwie nie jest kobietą - jest „zmarnowanym materiałem na kobietę", której odebrano możliwość prawdziwego życia.

Co ciekawe, owo identyfikowanie wyrzeczenia się sfery seksualno-erotycznej $\mathrm{z}$ całkowitą rezygnacją z jakiegokolwiek życia osobistego pojawia się również w wypowiedziach pochwalnych $-\mathrm{z}$ tą jedynie różnicą, że admiratorzy „władczyni absolutu" nadają temu ujęciu odcień nie pejoratywny, lecz sakralizujący. Deotyma zostaje wykreowana na kapłankę poezji, Sybillę (czemu niewątpliwie służyły świadome antyczne stylizacje, jak choćby biała szata w greckim stylu na słynnym

39 Cyt. za: P, s. 230; określenia „stare dziecko”, egzotyczna roślina, kwitnąca „umarłą krasą” pojawiają się w krytycznym artykule Jana Prusinowskiego pt. Kilka stów o Deotymie, opublikowanym w krakowskim „Czasie” (cz. I, nr 134, 1854, s. 1-2; cyt. za: I. Woszczak, Deotyma (Jadwiga Euszczerwska) w witrynie artystycznej ewaluacji..., op. cit., s. 52).

40 J.W. Gomulicki, op. cit., s. 34. 
obrazie Józefa Simmlera), a nawet „dziewicę-bohatera”. I nie jest to bynajmniej określenie przesadne, skoro stary Koźmian w początkowych słowach zachwytu przyrównywał ją do Joanny d'Arc, której boskim zadaniem będzie oczyszczenie polskiej literatury ${ }^{4 \mathrm{I}}$ (nawiasem mówiąc, krótko obcięte po chorobie włosy nastoletniej Jadwigi wymodelowano właśnie w fryzurę à la Jeanne d'Arc - P, s. 88). Skojarzenia takie często wiązano z jej osobą, również po upływie pierwszej i drugiej młodości: w czasie fet i uroczystości, organizowanych dla słynnej improwizatorki w czasie jej pobytu w Poznańskiem w I856 roku, jedna z jej wielbicielek napisała wiersz, w którym pojawiły się słowa: „Niech nam żyje wieszczka męczennica, niechaj nam w drogę przyszłości przyświeca" ${ }^{42}$, a w czasie pogrzebu poetki w 1908 roku Hajota (Helena Pajzderska) w swojej mowie użyła określeń: „westalka”, „dziewicza karmicielka ducha"43 (a zatem matka i dziewica jednocześnie; przy tym matka ważniejsza od biologicznej, bo duchowa). Nimb wyrzeczenia i ofiary towarzyszył zatem Deotymie aż do grobu.

We wspomnieniach samej Łuszczewskiej nacisk zostaje położony jednak na zupełnie inne sfery egzystencji, takie jak, doświadczenia religijne, przyjaźń, która była dla niej niezmiernie istotnym uczuciem, a przede wszystkim praca i stałe doskonalenie warsztatu twórczego. $Z$ niejakim zaskoczeniem można stwierdzić, że są to wartości tradycyjnie łączone z mężczyznami ${ }^{44}$.

Znacznie więcej miejsca niż ewentualnym zawodom uczuciowym ${ }^{45}$ na kartach swoich wspomnień Łuszczewska poświęca skrywanemu nawet przed najbliższymi

41 Pisał tak: „Ja ją uważam za ową dziewicę orleańską, ową prostą pasterkę, natchnioną z nieba, aby uwolniła Francję od rozpasanych i łupieżnych Anglików, którą oni jak czarownicę spalili. Kto wie, niezbadane są wyroki Opatrzności, czyli i nasza młoda dziewica nie jest przeznaczoną na uwolnienie literatury naszej od tych bękarcich, chciwych, łupieżnych powiastkopisarzy, bezbożnych lub płaskich, ciemnych, niezrozumiałych poetów, nadymających się imieniem wieszczów” (Cyt. za: I. Woszczak, Sekrety i porywy późnej twórczości..., op. cit., s. 105).

42 Wiersz Marii z Mańkowskich Kwileckiej Improwizacja poświęcona Pani Deotymie, cyt. za: K. Tokarzówna, op. cit., s. 386.

43 Opis pogrzebu i treść kilku wygłoszonych nad grobem Łuszczewskiej mów zamieścił Aleksander Kraushar w tekście Deotyma. Tragedia pozgonna żywota i twórczości poetki, w: idem, op. cit., s. 65, 66.

44 W tym kontekście warto wspomnieć o popularnych sztambuchowych wierszykach pióra Niny Łuszczewskiej pt. Przeznaczenie kobiety („Kochać w milczeniu, / Mówić w spojrzeniu, / Cierpieć w westchnieniu, Żyć w poświęceniu”) i Przeznaczenie mężczyzny (Mądrości berło piastować, / Ludzkość miłością owionąć, / Potęgą czynu panować, / A duszą w Bogu zatonąć") - cyt. za: P. Wilkońska, Wieczory poniedziatkowe u pani Niny Euszczewskiej, w: eadem, Moje wspomnienia o życiu towarzyskim w Warszawie, oprac. Z. Lewinówna, red. J.W. Gomulicki, Warszawa 1959, s. 52. Mimo wyraźnego etosu poświęcenia i chętnego podkreślania swojego domatorstwa, młodsza córka wyraźnie nie mieściła się w ramach zakreślonego przez matkę na potrzeby społecznej konwencji „podziału ról płciowych”.

45 Sama Jadwiga Łuszczewska twierdziła tylko w swoich wspomnieniach, że łączył ją z rodzicami stosunek pełen absolutnej szczerości i zaufania, więc zaakceptowałaby każdego kandydata do ręki, którego by jej wybrali, i na odwrót, rodzice „niezawodnie” przyjęliby jej dowolny wybór - „Ale ani jeden, ani drugi z tych wypadków nigdy się nie zdarzył" (P, s. 119). 
kryzysowi wiary, który trwał przez około dwadzieścia lat, a zakończył się jej tryumfalnym odzyskaniem w I875 roku. Ów przełom duchowy stał się według niej główną motywacją do pisania powieści, aby w kształcie „przystępnym a wabiącym” podzielić się swym przekonaniem z czytelnikami, bowiem:

1) Trzeba jeszcze wiedzieć, że podobne zwycięstwo przynosi taką radość, takie upojenie, o jakich żadne inne zachwyty nie mogą dać pojęcia. I co najpiękniejsze, to, że daje nie tylko radość, ale i niezwalczona chęć podzielenia się tym szczęściem z drugimi duszami. Człowiek chciałby z dachów ogłaszać swoje wielkie odkrycie, chciałby na placach otrąbywać, że to, co poddawał wątpieniu lub przeczeniu, to jednak jest! Naprawdę jest! Niezawodnie jest! (P, s. I62)

Dojrzała Deotyma w poezjach i powieściach zaczyna wprowadzać wątki romansowe, ustawiając się w bezpiecznej pozycji nieco sceptycznej obserwatorki, która prowadzi z ciekawością „studia idealno-artystyczne” na swoim otoczeniu (P, s. I56). W późnej twórczości „starodawny romansik”, czyli Panienka (I893, w I898 roku jako Panienka z okienka), zdradza jej żartobliwy i zdystansowany stosunek do miłości, wyrażony choćby w takich stwierdzeniach: „co do zdania, ile razy człek naprawdę się kocha, tego żaden psycholog jeszcze nie rozwiązał, bo każdemu zakochanemu za każdym razem się wydaje, że to dopiero jest pierwszy raz «naprawdę»", czy „Panny zaś po kątach aż piszczały z radości, a w duchu zazdrościły tej pannie, co była dosyć szczęśliwa, aby przechodzić tak piękne nieszczęścia"46. Znacznie gorętszy ton pojawia się w wypowiedziach na temat uczucia przyjaźni, któremu pisarka postanowiła poświęcić osobną powieść ${ }^{77}$. „Przymiarką” miał być dramat Narzeczona z Ogrodzieńca (1872), zaś wymarzoną realizacją - ukończone w I879, a wydane dopiero w 1889 roku (zresztą w wersji znacznie okrojonej przez cenzurę) Branki w jasyrze, dedykowane wieloletniej bliskiej przyjaciółce, Eugenii ze Zdzienieckich Wolffowej. Nie wdając się w ocenę wartości literackiej dzieła (uznawanego na ogól za niezbyt fortunny mariaż stylizacji na średniowieczną hagiografię i egzotycznych szczegółów etnograficznych ${ }^{48}$ ), należy jednak przypomnieć informację samej autorki, dotyczącą zamierzonej konstrukcji postaci w powieści, którą planowała jako pochwałę wiernej kobiecej przyjaźni:

46 Deotyma (Jadwiga Euszczewska), Panienka z okienka: starodawny romansik, Gdańsk 2007, s. 80, 207.

47 Łuszczewska pisze wprost: „Dawno już dziwiłam się i gniewałam, czemu pisarze przeznaczają w swoich utworach tak przesadnie szerokie miejsce dla ziemskiej Miłości, a po macoszemu się obchodzą z jej niebiańską siostrą Przyjaźnią, która jednak w życiu tyle znaczy, nierównie więcej niż w książkach?" (P, s. 162-163).

H. Markiewicz, op. cit., s. 202. 
\Toteż mylą się grubo ci krytycy, którzy w Brankach szukają głównego bohatera. Nie ma go tam wcale. Jest wprawdzie para pierwszorzędna, ale to nie bohater i bohaterka, tylko dwie bohaterki, wkoło których dopiero ustawiają się różne postacie męskie, wszystkie drugorzędne (P, s. I63).

Własną twórczość oceniała Deotyma bardzo krytycznie - jej wypowiedzi, zawarte w Pamiętniku, można oczywiście postrzegać jako realizację toposu afektowanej skromności, „minoderię” i obłudne wymuszanie od czytelników komplementów, nie sposób jednak zaprzeczyć, że ciężko pracowała nad swoimi tekstami, gromadząc materiały, latami szykując się do urzeczywistniania kolejnych pomysłów i wielokrotnie przerabiając gotowe już prace. Wiele dzieł, powstałych w młodych latach, trafiało do szafy z rękopisami nieprzeznaczonymi do wydania, ochrzczonej mianem „mauzoleum”. Jako samodzielna autorka, wolna już od wpływu rodziców, Jadwiga Łuszczewska nie decydowała się na tak pochopne drukowanie swoich improwizacji, za pisanie powieści zabrała się dopiero po ukończeniu czterdziestego roku życia - zgodnie z decyzją, podjętą wspólnie jeszcze za życia państwa Łuszczewskich, miała to być magiczna data, po której przekroczeniu nabywa się już wystarczająco wiele życiowych doświadczeń (P, s. I59-160). Okazało się jednak, że sam wiek nie wystarczy - jak stwierdziła początkująca powieściopisarka o swoich pierwszych próbach beletrystycznych, którymi były dwie powieści współczesne (Na rozdrożu i Krzyż nad otchtania):

\Z Że je napisałam, to nic nie szkodzi; były one dla mnie twardą i owocną szkołą. Szkoda tylko, że je wydrukowałam. [...]

Krytyka obeszła się z nimi surowo i bardzo sprawiedliwie uczyniła. Mnie jednak jej sądy wcale nie odjęły fantazji. Że próbne balony poleciały w złą stronę, to jeszcze nie wielkie nieszczęście. Dobra nauka, jak i którędy puszczać je na przyszłość (P, s. I6o).

Nauka ta trwała jeszcze długo, skoro Łuszczewska za rok osiagnięcia „umysłowej dojrzałości" i pełnego opanowania warsztatu uznawała dopiero rok I892, a zatem dokładnie czterdziestolecie (!) swojej pracy twórczej (począwszy od debiutu improwizatorskiego w salonie rodziców), tak pisząc o swoim zwycięstwie:

\Szkoda tylko, że ta dojrzałość przyszła tak późno, w chwili kiedy miałam już lat pięćdziesiąt osiem i kiedy ciało już zaczęło na dobre wypowiadać służbę! Nowy to dowód, że człowiek składa się z dwóch 
istot, nierównomiernych sobie nie tylko pierwiastkami, lecz i wiekiem. Oto ze mnie jest jeden przykład więcej, że istota materialna już się starzeje i już w pył się kruszy, podczas kiedy istota duchowa dochodzi dopiero do swej pełnoletniości (P, s. I72).

\section{DEOTYMY PORTRET WŁASNY}

Jadwigę Łuszczewską - jako osobowość i jako autorkę - na pewno ukształtowało kilka decydujących czynników. Pierwszym z nich był fakt prowadzenia przez rodziców, a właściwie przez ambitną matkę, salonu literackiego. Ów salon Niny Łuszczewskiej musiał zajmować niesłychanie istotne miejsce w egzystencji rodziny, skoro pierwszy rozdział Pamiętnika nie jest poświęcony (jak można byłoby się spodziewać) dzieciństwu, ale nosi tytuł Wieczory poniedziatkowe.

W tymże rozdziale znajdują się literackie portrety rodziców, z którymi Deotyma była silnie związana emocjonalnie. Oboje są przedstawieni jako ludzie niezwykli, o wielkiej wartości, ale wyraźnie widać różnicę - o ile piękna i „olśniewająca” matka budzi u autorki dumę i podziw, o tyle bezkrytyczne uwielbienie zarezerwowane jest dla idealizowanego ojca, w którym widzi się wzór wszelakich cnót, uosobienie poświęcenia i samozaparcia, „słoneczną oś życia”49. Można rzec, że Jadwiga dosłownie ubóstwia ojca:

\section{\) Zawsze pogodny, zawsze sprawiedliwy, zawsze niezachwiany w zasa- dach religii, obowiązku i patriotyzmu, przedstawiał on dla mnie coś boskiego. Przed długie nawet lata nie mogłam sobie Bóstwa wyobrazić inaczej, tylko w postaci Boga-Ojca. Pojęcie ojcostwa było dla mnie zawsze równoznacznikiem najwyższej doskonałości, niewyczerpanego przebaczenia i opatrznościowej opieki (P, s. 76).}

To ojciec był pierwszym słuchaczem i krytykiem utworów córki, on towarzyszył jej w podróżach po kraju i wyprawach za granicę (rzadziej - oboje rodzice). Bardzo wyraziście tę odmienność w relacjach między utalentowaną córką a ojcem oraz

49 Wedle innych świadectw Wacław Łuszczewski prezentuje się znacznie mniej posągowo, jako człowiek poczciwy i uczony, ale potulny, niezbyt odważny i zahukany przez żonę (złośliwie nazywany „Ninusem”). Ten „idealny urzędnik” bardzo źle znosił wygnanie do Rosji, mimo troskliwej opieki córki, która nie tylko nadspodziewanie sprawnie prowadziła dom zesłańca jako gospodyni, a zarazem służąca, ale także zdecydowała się na pisanie do matki po francusku listów, wychwalających kulturę i kraj zaborcy - listy te pani Nina rozpowszechniała, licząc na ułaskawienie męża. O dziwo, nikt tego epizodu Deotymie nie wytykał - najwidoczniej uznano, że miłość do ojca uświęca i takie niegodne środki (zob. I. Woszczak, Deotyma (Jadwiga Euszczerwska) w witrynie artystycznej ewaluacji..., op. cit., s. 52-53). 
matką widać we wspomnieniu pierwszej spontanicznej improwizacji, wygłoszonej w czasie rozmowy z Wacławem Łuszczewskim z czystej ciekawości, czy Jadwiga potrafi mówić wierszem na dowolny temat tak, jak to czyniła w dzieciństwie. Po wysłuchaniu szambelan jest zadowolony, choć zwraca uwagę na nieśmiały, drżący głos córki, matka zaś na propozycję rozemocjonowanej debiutantki: „Gdyby mama chciała, to mogłabym i przed nią spróbować”, reaguje ze zdumiewającym chłodem:

》 „Ani myślę - odpowiedziała. - Już jeśli masz się wysilać, to przynajmniej dla większej liczby słuchaczów. Trafi ci się do tego niejedna sposobność.” I wyszła z pokoju, ani myśląc mnie słuchać (P, s. 95).

Dlatego też bulwersująca Juliusza Wiktora Gomulickiego kwestia pochówku Deotyma została pochowana na Powązkach razem z ojcem, matka zaś spoczywa gdzie indziej z pozostałą rodziną - która przez biografa jest interpretowana jako jedyny i ostatni, milczący, ale tym bardziej dobitny wyrzut pod adresem egocentrycznej rodzicielki ${ }^{50}$, może mieć bardziej złożoną wymowę. Może jednak należy tę decyzję postrzegać (podobnie jak wybór Jadwigi w roku I863) nie jako demonstrację przeciw matce, ale wyraz nieugiętej solidarności z ojcem? Wacław Łuszczewski został bowiem pochowany $z$ dala od pozostałych krewnych jeszcze za życia żony (i zapewne za jej wolą), a żaden z badaczy nie pokusił się dotychczas o wyjaśnienie tego faktu pośmiertnego wygnania byłego zesłańca spomiędzy rodzinnych grobowców.

Bardzo silny (niekiedy uznawany przez biografów za wręcz chorobliwy) związek z rodzicami został wzmocniony przez szczególne wychowanie, obmyślone przez Ninę Łuszczewską, „przetestowane” najpierw na starszej córce, a udoskonalone na młodszej5 ${ }^{5}$. Dziewczęta nie miały żadnych guwernantek, uczyli je wyłącznie rodzice, przede wszystkim wpajając szacunek dla języka ojczystego, historii, religii; aby tym lepiej kontrolować wszelkie „obce wpływy”, zabraniano im zabawy z innymi dziećmi. Niemal nieustanne przebywanie w towarzystwie dorosłych miało zmusić córeczki do szybszego dorośnięcia do ich poziomu. Ustępstwa poczyniono na rzecz tradycyjnych kobiecych umiejętności (gospodarstwo, robótki, język francuski), w „zajęciach umysłowych” stosując godną Rousseau metodę stawiania

50 J.W. Gomulicki, op. cit., s. 36.

51 Tak na przykład kilku nauczycieli, wynajmowanych dla Kazimiery, matka uznała za „zbyt wielu” i dla Jadwigi zatrudniono już tylko dwóch, choć znakomitych - Józefa Sikorskiego od muzyki i prof. Antoniego Wagę do nauk przyrodniczych i języka polskiego. Mała Jadwiga upodobała sobie zdumiewająco zróżnicowane przedmioty - arytmetykę, astronomię i muzykę, co po latach interpretowała jako wrodzony pociąg do szukania rytmu w różnych kształtach i objawach (P, s. 77-78). 
na „twórczość”, nie na pamięciowe opanowanie informacji. Łuszczewska ocenia ten system edukacyjny następująco:

》 Toteż przy odrabianiu zadań i wypracowań nie wolno nam było radzić się starszych ani żądać niczyjej pomocy. Wszystko się musiało robić z własnej głowy, własnym wysileniem. System to, z początku dla dziecka ciężki, ale wyborny, jedyny, który wyrabia s a m od zi eln oś ć myśli (P, s. 7i - wyróżn. A. B.).

Ten szacunek dla dawnych autorytetów, w oryginalny sposób połączony z niezależnością myślenia, da się odnaleźć po latach w tekście odczytu z I88I roku poświęconego sylwetce zapomnianej i niedocenianej Klementyny z Tańskich Hoffmanowej. Znacznie bardziej zapewne odpowiada on rzeczywistym poglądom Łuszczewskiej niż - niejednokrotnie wzajemnie sprzeczne - sądy jej powieściowych bohaterów. W swojej „pogadance” Deotyma protestuje przeciw bezwzględnemu dyktatowi opinii publicznej (pytając przekornie: „Trzebaż głowę skłaniać zawsze przed jakąkolwiek bądź opinią? Trzebaż się dać porwać każdemu jej prądowi? A niechże nas Bóg broni!”), zaś popularne w latach pozytywistycznej kampanii w sprawie kwestii kobiecej oskarżenia o zacofanie i ograniczenie autorki Pamiątki po dobrej matce kwituje stwierdzeniem: „Nieśmiała? Ona stokroć śmielsza niż my wszystkie, bo pier w z z a"52. Uznanie pokory autorki „dziwnie sprytnej rewolucji” za właściwy klucz do powolnych, lecz skutecznych przemian społecznych (wszak „przeba cz o n o jej tę samodzielność i tę wyższość”); twierdzenie, że literatura dziecięca należy do najtrudniejszych i najbardziej odpowiedzialnych gatunków (bo to ona kształtuje przyszłego czytelnika); pochwała najwyższej sztuki prostoty stylu; program wychowawczy skromny, ale uniwersalny, bo pisany dla ogółu; szacunek dla codziennych prac, rzeczy zwykłych, których „nie ma zasługi umieć, ale jest wstyd nie umieć"53 - czytając te uwagi, nie sposób pozbyć się wrażenia, że Deotyma bardzo silnie utożsamia się z tak gorąco bronioną Hoffmanową, gdy wzdycha: „Daj Boże, aby nasi duchowi następcy umieli nas osądzić nie według swojej epoki, ale według naszej”54.

52 Deotyma, Klementyna Hoffmanowa wobec nowych pokolen, „Kronika Rodzinna. Pismo dwutygodniowe poświecone literaturze, sprawom społecznym i domowym”, 1881, t. 9, seria 4, nr 2, s. 1-2.

Ibidem, s. 5.

54 Ibidem, s. 10. 


\section{ZAKOŃCZENIE}

Zarzucano Łuszczewskiej często, że jej improwizacje są poezjami chłodnymi i wyrozumowanymi, a powieści stanowią popis nużącej erudycji - co ciekawe, te same zarzuty w podobnych słowach formułują na przykład młody publicysta „Przeglądu Tygodniowego” $i$ jeden z romantycznych wieszczów (wedle Krasińskiego to „poezja wiedzy i wyłącznie wiedzy”, co prawda „prześlicznie zwierszona” - „lecz czucia tam nie masz i żeńskości żadnej”55). Brak „kobiecego uczucia” musiał być niemal dominującą cechą dla wychowanych wedle dziewiętnastowiecznych norm obserwatorów, skoro zakochany w Brankach w jasyrze młody sandomierski księżyk, Józef Rokoszny, ze zdumieniem odnotowywał swoje pierwsze wrażenia po spotkaniu z uwielbianą pisarką w I9or roku: „Wpatrywałem się w tę staruszkę (miała już wówczas około 70 lat) i chciwie szukałem w niej cechy poezji. Znalazłem przede wszystkim rozum ${ }^{\prime 56}$.

Posunięta w latach Jadwiga Łuszczewska jako wielka dama o nieskazitelnych manierach, jednym spojrzeniem trzymająca w ryzach gości swojego salonu ${ }^{57}$, imponująca erudycją i pracowitością - to obraz, jaki pozostawili jej życzliwi goście. Znacznie popularniejszy (i trwalszy!) był groteskowy wizerunek oderwanej od realnego życia i zadufanej w sobie „wieszczki”, budowany najczęściej na podstawie wspomnień osób trzecich, a rozpowszechniany na prawach barwnej anegdoty.

Łatwo było bowiem wykpiwać Deotymę, złośliwie przekręcając jej artystyczny pseudonim („Teodyma” $\left.{ }^{8}\right)$, powtarzając plotki o „złotolitym tronie” i komicznie pretensjonalnej ceremonialności spotkań czy układając wierszyki w rodzaju:

\section{》Deotyma \\ się nadyma; \\ Zamiast kiecki \\ ma strój grecki ${ }^{59}$}

albo ten (przypisywany Sienkiewiczowi):

55 Listy Zygmunta Krasińskiego do Augusta Cieszkorwskiego, t. 2: Listy z lat 1848-1859, wyd. J. Kallenbach, wstęp A. Żółtowski, Kraków 1912, s. 334, 335.

56 J. Rokoszny, Wspomnienia o Deotymie, Radom 1934, s. 9.

57 Czesław Jankowski wspominał pioruny, jakie rzucały oczy poetki, gdy ktoś ośmielił się kręcić podczas jej recytacji: „A niechże kto, Boże nie daj, w krzesło trącił, chrząknął, kichnął, a - co już było ostateczną katastrofą - zagadał do sąsiada lub sąsiadki! Dwa, trzy godziły w niego spojrzenia. Od czwartego byłby chyba trupem padł" (Cz. Jankowski, op. cit., cyt. za: P, s. 201).

58 M. Samozwaniec, Maria i Magdalena, t. 1, Szczecin 1989, s. 136.

59 Zob. B. Krzywobłocka, Wieszczka Deotyma, w: eadem, Delfina i inne, Warszawa 1970. (Ten popularny artykuł zawiera sporo omyłek chronologicznych i daleko idących uproszczeń). 
\Wlazł kotek na płotek i mruga:

Dość lodów, Deotymy i Pługa!

Niewątpliwie trudniej przychodziło zastanowienie się nad jej wyborami i motywacjami, nie ulegając przy tym dominującym w danym momencie nastrojom bałwochwalstwa czy przeciwnie, surowej i często niezbyt sprawiedliwej krytyki. Podobnie trudna jest ocena rzeczywistej wartości salonów literackich, tak państwa Łuszczewskich, jak i samej Deotymy ${ }^{60}$ - usiłując wyrobić sobie dziś własną opinię, musimy być wyczuleni na arbitralność ocen wygłaszanych przez współczesnych, zważać na niebezpieczną skłonność do projektowania na przeszłość dzisiejszego, nieraz zniekształconego obrazu, oraz pamiętać o specyfice kontekstu: historycznego, biograficznego i kulturowego. Jadwiga Łuszczewska już jako debiutantka dostąpiła pod piórem wielbicieli i przeciwników specyficznej apoteozy - właściwie przestała być żywą, realną kobietą, stała się „osobliwością”, „,enomenem”, „zjawiskiem”. W bardzo trafny sposób ujmuje to badaczka pierwszego okresu jej twórczości, stwierdzając:

1) Można sobie tylko wyobrazić, jak wiele pokory i cierpliwości było w tej młodej dziewczynie, skoro z uśmiechem i dziękczynieniem przyjmowała, do znudzenia powtarzane, utyskiwania starszych. Musiała mieć wiele wewnętrznej siły, ażeby, będąc rozdartą między aspiracjami matki, rodziny i gości salonu, a często sprzecznymi poleceniami literackich autorytetów, którym przecież ufała, pozostać we względnej harmonii ze sobą i światem. Dodajmy do tego ogromny stres, towarzyszący improwizacjom i poczucie odpowiedzialności nie tylko względem najbliższych, lecz także społeczeństwa; wreszcie niezrozumienie, samotność dziewczyny, którą traktuje się z nadmiernym uwielbieniem lub złośliwością, a z pewnością nie jak czującego człowieka, lecz fenomenalne zjawisko, i mamy materiał na psychiczne wykolejenia lub załamanie nerwowe ${ }^{6 \mathrm{r}}$.

Łuszczewska ani jako kobieta, ani jako artystka nie wykoleiła się - wręcz przeciwnie, postawiona w obliczu konieczności potrafiła okazać wiele hartu, do końca

60 Najcelniej chyba kulturowy walor salonu Deotymy w latach siedemdziesiątych ujęła Baronowa XYZ, pisząc o jej wieczorach: „A przede wszystkim były prawie jedyne, a więc przez to samo niezmiernie ponętne” (Baronowa XYZ [Antoni Zaleski], Towarzystwo warszawskie. Listy do przyjaciótki, t. 2, Kraków 1887, cyt. za: P, s. 196). Kompensowanie sobie w formie „nieszkodliwej zabawy” braku normalnego funkcjonowania sfery publicznej w Warszawie pod zaborami nie powinno również przysłaniać faktu, że u „wieszczki” na neutralnym gruncie spotykali się ludzie niekiedy z bardzo różnych środowisk, m.in. inteligencja i kupiectwo pochodzenia żydowskiego.

61 I. Woszczak, Sekrety i porywy późnej twórczości..., op. cit., s. 110. 
starała się pisać i prowadzić aktywne życie, przynajmniej pod względem duchowym $\mathrm{i}$ intelektualnym. O tym, że do końca była to niepospolita i silna osobowość, warta dalszego badania jako intrygująca przedstawicielka swojej epoki, świadczą choćby słowa zgryźliwego Felicjana Faleńskiego, tego samego, którego rzucone zza grobu pomówienia takim cieniem legły na jej opinii. O ostatnich latach Deotymy weredyk Faleński pisał tak:

\Wreszcie z wiekiem przyszło niezdrowie, aż i obecnie coraz silniej jest cierpiącą i prawie już chodzić nie może. Garstka odwiedzających ją coraz się ścieśnia. Czasami zastać ją można najzupełniej samą. Z tym wszystkim nic nie robi dla ulżenia sobie cierpień. Po dawnemu nocami żyje, nadmiernie pracuje; zachowała jednak całą żywość umysłu, a nawet - powiedzieć można - bardzo jej jakoś wypogodniała dusza, co bywa tylko wyższych usposobień udziałem ${ }^{62}$.

\section{Bibliografia:}

[Białobłocki B.], Życie fikcyjne i obrzędowe. (Przyczynek do studium nad Deotyma i kierunkiem naszej literatury), cz. I-IV, „Przegląd Tygodniowy” nr 16-19, 1883;

Biernacki A., hasło: Łuszczerwska Jadwiga, w: Polski stownik biograficzny, t. XVIII, Wrocław 1973;

Deotyma (Jadwiga Euszczewska), Pamiętnik 1834-1897, wstępem i przypisami opatrzył J.W. Gomulicki, Warszawa 1968;

Deotyma, Panienka z okienka, Gdańsk 2007;

Deotyma, Klementyna Hoffmanowa wobec nowych pokolen, „Kronika Rodzinna. Pismo dwutygodniowe poświecone literaturze, sprawom społecznym i domowym", 1881, t. 9, seria 4, nr 2;

Faleński F., Wspomnienia z mojego życia, wyd. i oprac. J. Rudnicka, w: Miscellanea z pogranicza XIX i XX wieku, Wrocław 1964 („Archiwum Literackie VIII”);

Gomulicki J.W., O salonie literackim dwóch pań Łuszczerwskich [wstęp], w: Deotyma (Jadwiga Łuszczewska), Pamiętnik 1834-1897, wstępem i przypisami opatrzył J. W. Gomulicki, Warszawa 1968;

Jankowski Cz., Z czeczotkowej szkatutki. Odgtosy ginacego świata, Wilno 1926;

Kopeć J., „Czwartek” u Deotymy, w: eadem, Dziecko dawnej Warszawy, Warszawa 1958;

Kraushar A., Deotyma. Tragedia pozgonna żywota i twórczości poetki, w: idem, Polki twórcze czasów nowszych, Warszawa 1929;

Krzywicki L., hasło: Biatobtocki Bronistaw, w: Polski stownik biograficzny, t. II, Kraków 1936;

Krzywobłocka B., Wieszczka Deotyma, w: eadem, Delfina i inne, Warszawa 1970;

Krzyżanowski J., Dobre chęci Deotymy, w: idem, W kręgu wielkich realistów, Kraków 1962;

Oppman A., Czwartki u Deotymy, w: Deotyma (Jadwiga Łuszczewska), Pamiętnik 1834-1897, wstępem i przypisami opatrzył J. W. Gomulicki, Warszawa 1968;

Rokoszny J., Wspomnienia o Deotymie, Radom 1934;

62 F. Faleński, op. cit., cyt. za: P, s. 194. 
Tokarzówna K., Odwiedziny „wieszczki”, w: Literackie przystanki nad Warta, red. Z. Szweykowski, Poznań 1962;

Tyrowicz M., hasło: Faleński Felicjan, w: Polski stownik biograficzny, t. 6, Kraków 1946;

Weintraub W., hasło: Improwizacja, w: Stownik literatury polskiej XIX wieku, red. J. Bachórz i A. Kowalczykowa, Wrocław-Warszawa-Kraków 1991;

Wilkońska P., Wieczory poniedziatkowe u pani Niny Euszczerwskiej, w: eadem, Moje wspomnienia o życiu towarzyskim w Warszawie, oprac. Z. Lewinówna, red. J.W. Gomulicki, Warszawa 1959;

Woszczak I., Deotyma (Jadwiga Euszczerwska) w witrynie artystycznej erwaluacji pierwszego okresu twórczości (1851-1863): prasa, wspomnienia, korespondencja, „Prace Polonistyczne”, seria 69, 2014;

Woszczak I., Sekrety i porywy późnej twórczości, czyli o przyjaźni, wzajemnej fascynacji i rozczarowaniach taczacych Franciszka Wężyka, Kajetana Koźmiana i Antoniego Edwarda Odyńca z Deotyma, „Prace Polonistyczne", seria 67, 2012;

Zakrzewski B., „Istotnie, Bóg dat Polsce genialna poetke”. Rzecz o mickiewiczowskim falsyfikacie, w: idem, „Spowiednicy” Mickierwicza i Fredry, Wrocław 1994.

SŁowa KLucze: Deotyma (Jadwiga Łuszczewska), salon, improwizacja, krytyka, zjawisko kulturowe

\section{Agnieszka Bąbel \\ Problems with Deotyma}

The article presents contradictory opinions about Jadwiga Euszczewska (Deotyma) and her artistic works expressed by her contemporaries and future generations. These opinions are contrasted with the image of the poet that emerges from her Pamiętniki 1834-I897 [Memoir I834-1897]. Selected critical comments are set in the cultural context of the time (for example the phenomenon of poetical improvisation and a literary salon) and also set against certain biographical information. An attempt has been made to indicate possible reasons for enormous fascination, intense dislike or treatment with condescension that Deotyma herself and her controversial life choices arouse.

Key words: Deotyma (Jadwiga Łuszczewska), literary salon, improvisation, criticism, cultural phenomenon 